|| ISSN(online): 2589-8698 || ISSN(print): 2589-868X ||

International Journal of Medical and Biomedical Studies

Available Online at www.ijmbs.info

NLM (National Library of Medicine ID: 101738825)

Index Copernicus Value 2020: 79.44

Volume 5, Issue 12; December: 2021; Page No. 76-79

\title{
A COMPARATIVE STUDY OF INTRAVENOUS IRON SUCROSE VERSUS ORAL IRON THERAPY IN IRON DEFICIENCY ANEMIA DURING POSTPARTUM PERIOD
}

\section{Dr. Satish Kumar}

Department of Obstetrics \& Gynecology, S.P. Medical College and Associated Group of Hospitals, Bikaner (Rajasthan) India.

Article Info: Received 14 October 2021; Accepted 04 December 2021

DOI: https://doi.org/10.32553/ijmbs.v5i12.2345

Corresponding author: Dr. Satish Kumar

Conflict of interest: No conflict of interest.

Abstract

Introduction: Anemia is the commonest major contributing factor in maternal mortality and morbidity in developing countries and according to World Health Organization (WHO) criteria, it contributes to $20 \%$ of maternal deaths. Anemia in pregnancy defined as hemoglobin level $<11 \mathrm{gm} / \mathrm{dl}(7.45 \mathrm{mmol} / \mathrm{L})$ and hematocrit less than $33 \%$ (WHO).

Aim: To compare the efficacy of oral iron ferrous sulphate therapy with intravenous iron sucrose therapy in the treatment of iron deficiency anemia during postpartum period.

Material \& Methods: This was a prospective randomized comparative clinical trial single center study conducted on 200 postpartum women aged $>18$ years (after normal delivery or LSCS) within 10 days of delivery with Hb level more or equal to $6 \mathrm{gm} / \mathrm{dl}$ but less than $10 \mathrm{gm} / \mathrm{dl}$ were included in the study. This was a one year study conducted during $1^{\text {st }}$ December 2018 to $30^{\text {th }}$ November 2019.

Results : There was a significant increase in the hemoglobin level in both the groups i.e. in IV iron group, from 8.26 $\pm 1.03 \mathrm{gm} / \mathrm{dl}$ on day 1 to $11.62 \pm 0.94 \mathrm{gm} / \mathrm{dl}$ on day 45 as compared to oral iron group, from $8.24 \pm 1.09 \mathrm{gm} / \mathrm{dl}$ on day 1 to $11.07 \pm 1.14 \mathrm{gm} / \mathrm{dl}$ on day 45 ; and serum ferritin level from $41.69 \pm 40.45 \mathrm{ng} / \mathrm{ml}$ on day 1 to $77.34 \pm 41.60 \mathrm{ng} / \mathrm{ml}$ on day 45 in IV iron group as compared to the oral iron group from $22.20 \pm 8.82 \mathrm{ng} / \mathrm{ml}$ on day 1 to $31.72 \pm 9.72 \mathrm{ng} / \mathrm{ml}$ on day 45 . So, there was a rapid increase in both hemoglobin and serum ferritin levels in IV iron group as compared to the oral iron group.

Conclusion: Intravenous iron sucrose administration increases the hemoglobin level and serum ferritin more rapidly in compare to the oral intake of ferrous sulphate in women with iron deficiency anemia in postpartum women in our study. Keywords: Iron deficiency anemia, Intravenous iron sucrose, Serum ferritin, Maternal mortality.

\section{Introduction}

Anemia is the commonest major contributing factor in maternal mortality and morbidity in developing countries and according to World Health Organization (WHO) criteria, it contributes to $20 \%$ of maternal deaths. Anemia in pregnancy defined as hemoglobin level $<11 \mathrm{gm} / \mathrm{dl}(7.45$ $\mathrm{mmol} / \mathrm{L}$ ) and hematocrit less than $33 \%$ (WHO) ${ }^{1}$.

Nutritional iron deficiency is the most common deficiency disorder in the world, affecting more than two billion people worldwide, with pregnant women at particular risk ${ }^{2-4}$. World Health Organization states that iron deficiency anemia in pregnancy is a significant problem throughout the world with a prevalence ranging from an average of $14 \%$ of pregnant women in industrialized countries to an average of $56 \%$ in developing countries (range $35-75 \%)^{3,4}$.

Postpartum anemia is observed in up to $27 \%$ of women. Postpartum anemia defined as hemoglobin of less than 10 $\mathrm{gm} / \mathrm{dl}$ and serum ferritin less than $15 \mu \mathrm{g} / \mathrm{L}$ in $24-48$ hours of post-delivery period which is observed in upto $30 \%$ of women ${ }^{5}$.
Nutrition of a woman in the family is always being ignored because of various social and cultural practices and on the top of it, she always remains in the dark about her own health. High prevalence of iron deficiency is attributable to faulty diet habits, faulty absorption mechanism because of high prevalence of intestinal infestation and increased iron loss as consequence of repeated pregnancies at short intervals, excessive blood loss during menstruation, hookworm infestation and chronic malaria ${ }^{6}$.

In typical singleton gestation, the mother requires iron approximately $1000 \mathrm{mg}$. Out of these, $300 \mathrm{mg}$ is for the growing fetus and placenta, $500 \mathrm{mg}$ for maternal hemoglobin mass expansion and $200 \mathrm{mg}$ is shed normally through gut, urine and skin. The total demand of $1000 \mathrm{mg}$ exceeds the iron store of most women which results in iron deficiency anemia unless iron supplementation is given ${ }^{7}$.

At the present time, there is no consensus on the management of postpartum anemia. The standard approach to treatment in the majority of institutions is oral supplementation, with 
blood transfusion reserved for more severe or symptomatic cases $^{8}$.

There are number of hazards of blood transfusion including transfusion of wrong blood, anaphylaxis and risk of transmission of infections, any of which would be devastating for the young mother ${ }^{9}$. These hazards, together with the national shortage of blood products, mean that transfusion should be viewed as a last resort in otherwise young and healthy women ${ }^{10}$.

Parenteral iron administration with ferrous sucrose is now available and can be used for treatment of iron deficiency anemia in postpartum period ${ }^{11}$. Parenteral iron is an alternative for oral therapy provides a quick and certain correction of total iron deficit.

The current gold standard for checking for IDA includes looking at both the $\mathrm{Hb}$ levels and the serum ferritin values ${ }^{12}$. By the time a patient is anemic, they have already depleted their iron storage, as evidence by decreased levels of serum ferritin.

Hematologic changes, like $\mathrm{Hb}$ and ferritin, are fairly rapid with IV iron therapy and have a positive effect on the body's iron storage which is measured by the ferritin level. Iron sucrose has an excellent safety record, unlike older IV formulations such as ferrous dextran, which has been associated with a significant risk of anaphylactic reactions.

\section{METHOD}

This study was conducted in the Department of Obstetrics and Gynecology, S.P. Medical College\& Associated Group of Hospitals, Bikaner, Rajasthan.

Postpartum women with iron deficiency anemia (IDA) consenting to participate in the study, 200 women (100 in each group) met within the inclusion criteria were included from $1^{\text {st }}$ Dec. 2018 to $30^{\text {th }}$ Nov. 2019.

Inclusion criteria:

Postpartum women aged $>18$ years (after normal delivery or LSCS) during 24-48 hours post delivery within 10 days of delivery with $\mathrm{Hb}$ level more or equal to $6 \mathrm{gm} / \mathrm{dl}$ but less than $10 \mathrm{gm} / \mathrm{dl}$ were included in the study.

\section{Exclusion criteria:}

1. Women with intolerance to iron derivatives

2. $\mathrm{H} / \mathrm{O}$ acute thromboembolism, seizures or drug abuse

3. Women with signs of worm infestation

4. Evidences of renal or hepatic dysfunction
5. Diagnosed cases of anemia other than iron deficiency anemia for e.g. thalassemia

6. Chronic anemia

This was a hospital based, randomized, comparative, prospective, clinical study. The sample size of 200 women was selected from the postpartum women admitted in maternity ward after fulfilling the selection criteria. After careful history taking, clinical examination and minimal investigations other causes of anemia were ruled out. The initial iron status of the woman was assessed by the clinical and laboratory examinations (complete blood count, hemoglobin and serum ferritin levels).

Subjects were randomized and divided into 2 groups, each of 100 women:

1. Group 1- Received $400 \mathrm{mg}$ of Intravenous Iron sucrose divided in two doses of $200 \mathrm{mg}$ as an infusion in $300 \mathrm{ml}$ NS on alternate days (day $2 \&$ day 4$)+500 \mu \mathrm{g}$ folic acid orally daily for 6 weeks.

2. Group 2- Received $200 \mathrm{mg}$ oral ferrous sulphate divided into 2 doses, $100 \mathrm{mg}$ of each given $\mathrm{BD}+500 \mu \mathrm{g}$ folic acid daily for 6 weeks.

The post therapy evaluation was done with the estimation of hemoglobin and serum ferritin levels of both the treatment groups on day 14 and day 45 .

\section{Data Analysis}

The statistical analysis was performed using the Mean, Standard Deviation, Chi square test and t-test. Variations of $\mathrm{p}<0.05$ were considered to be statistically significant.

\section{RESULTS}

The baseline mean $\mathrm{Hb}$ was $8.26 \pm 1.03 \mathrm{gm} / \mathrm{dl}$ in IV iron group and $8.24 \pm 1.09 \mathrm{gm} / \mathrm{dl}$ in oral iron group (Table 1).

There was a significant increase in the hemoglobin level in both the groups i.e. in IV iron group, from $8.26 \pm 1.03 \mathrm{gm} / \mathrm{dl}$ on day 1 to $11.62 \pm 0.94 \mathrm{gm} / \mathrm{dl}$ on day 45 as compared to oral iron group, from $8.24 \pm 1.09 \mathrm{gm} / \mathrm{dl}$ on day 1 to $11.07 \pm 1.14$ $\mathrm{gm} / \mathrm{dl}$ on day 45; but, there was a rapid increase found in IV iron group as compared to the oral iron group (Table 1).

The baseline mean serum ferritin level in IV iron group was $41.69 \pm 40.45 \mathrm{ng} / \mathrm{ml}$ and in oral iron group was $22.20 \pm 8.82$ $\mathrm{ng} / \mathrm{dl}$ i.e. on day 1 (Table 2).

There was a significant rapid increase in the serum ferritin level from $41.69 \pm 40.45 \mathrm{ng} / \mathrm{ml}$ on day 1 to $77.34 \pm 41.60$ $\mathrm{ng} / \mathrm{ml}$ on day 45 in IV iron group as compared to the oral iron group from $22.20 \pm 8.82 \mathrm{ng} / \mathrm{ml}$ on day 1 to $31.72 \pm 9.72$ $\mathrm{ng} / \mathrm{ml}$ on day 45 (Table 2 ).

Table 1: Comparison of the mean and the standard deviation in hemoglobin levels in both the groups

\begin{tabular}{|l|l|l|l|l|}
\hline \multirow{2}{*}{$\begin{array}{l}\text { Day of Hemoglobin } \\
\text { estimation }\end{array}$} & IV Iron Group & OFS Group \\
\cline { 2 - 5 } & Mean & SD & Mean & SD \\
\hline Day 1 & 8.26 & 1.03 & 8.24 & 1.09 \\
\hline Day 14 & 10.25 & 1.06 & 9.64 & 1.04 \\
\hline Day 45 & 11.62 & 0.94 & 11.07 & 1.14 \\
\hline
\end{tabular}


Table 2: Comparison of the mean and the standard deviation in serum ferritin levels in both the groups

\begin{tabular}{|l|l|l|l|l|}
\hline \multirow{2}{*}{$\begin{array}{l}\text { Day of Serum Ferritin } \\
\text { estimation }\end{array}$} & \multicolumn{3}{|l|}{ IV Iron Group } & OFS Group \\
\cline { 2 - 5 } & Mean & SD & Mean & SD \\
\hline Day 1 & 41.69 & 40.45 & 22.20 & 8.82 \\
\hline Day 14 & 62.26 & 40.54 & 27.12 & 8.94 \\
\hline Day 45 & 77.34 & 41.60 & 31.72 & 9.72 \\
\hline
\end{tabular}

\section{DISCUSSION}

The mean baseline $\mathrm{Hb}$ (day 1) was $8.26 \pm 1.03 \mathrm{gm} / \mathrm{dl}$ in IV iron group and $8.24 \pm 1.09 \mathrm{gm} / \mathrm{dl}$ in oral iron group. On day 14 , there was a rapid increase in mean $\mathrm{Hb}$ from $8.26 \pm 1.03$ $\mathrm{gm} / \mathrm{dl}$ to $10.25 \pm 1.06 \mathrm{gm} / \mathrm{dl}$ in IV iron group as compared to the oral iron group i.e. from $8.24 \pm 1.09 \mathrm{gm} / \mathrm{dl}$ to $9.64 \pm 1.04$ $\mathrm{gm} / \mathrm{dl}$. On day 45 , there was an increase in mean $\mathrm{Hb}$ in both the groups i.e. from $10.25 \pm 1.06 \mathrm{gm} / \mathrm{dl}$ to $11.62 \pm 0.94 \mathrm{gm} / \mathrm{dl}$ in IV iron group and from $9.64 \pm 1.04 \mathrm{gm} / \mathrm{dl}$ to $11.07 \pm 1.14$ $\mathrm{gm} / \mathrm{dl}$ in oral iron group (Table 1).

This illustrated that there was a significant increase in the hemoglobin level from day 1 to day 45 in both the study groups; but, there was a rapid increase found in IV iron group as compared to the oral iron group.

The results are comparable to the study done by Vijaylakshmi et $\mathrm{al}^{9}$, in their study, in IV iron group, there was a significant increase in the mean $\mathrm{Hb}$ from $8.8 \pm 0.6$ $\mathrm{gm} / \mathrm{dl}$ on day 1 to $11.1 \pm 0.8 \mathrm{gm} / \mathrm{dl}$ on day 28 as compared to oral iron group, from $8.7 \pm 0.9 \mathrm{gm} / \mathrm{dl}$ on day 1 to $10.6 \pm 0.9$ $\mathrm{gm} / \mathrm{dl}$ on day 28 . The study done by Pradhan et $\mathrm{al}^{5}$ also comparable to our study, as in their study, there was a significant increase in the mean $\mathrm{Hb}$ from $7.822 \pm 0.542 \mathrm{gm} / \mathrm{dl}$ on day 1 to $12.858 \pm 0.661 \mathrm{gm} / \mathrm{dl}$ at the end of $6^{\text {th }}$ week (i.e. on day 45) as compared to oral iron group, from $8.008 \pm$ $0.543 \mathrm{gm} / \mathrm{dl}$ on day 1 to $9.889 \pm 0.9467 \mathrm{gm} / \mathrm{dl}$ at the end of $6^{\text {th }}$ week (i.e. on day 45 ). In the study done by Kharde et $\mathrm{al}^{13}$, in their study, there was a significant increase in the mean $\mathrm{Hb}$ in IV iron group i.e. from $7.47 \pm 0.767 \mathrm{gm} / \mathrm{dl}$ on day 1 to $11.41 \pm 0.790 \mathrm{gm} / \mathrm{dl}$ on day 40 as compared to oral iron group, from $7.76 \pm 0.713 \mathrm{gm} / \mathrm{dl}$ on day 1 to $10.78 \pm 0.767$ $\mathrm{gm} / \mathrm{dl}$ on day 40 . In the study done by Gupta et $\mathrm{al}^{6}$, also comparable to our study, as there was also a significant increase in the mean $\mathrm{Hb}$ in IV iron group i.e. from $7.23 \pm$ $0.57 \mathrm{gm} / \mathrm{dl}$ on day 1 to $11.24 \pm 0.53 \mathrm{gm} / \mathrm{dl}$ on day 30 as compared to oral iron group, from $7.33 \pm 0.41 \mathrm{gm} / \mathrm{dl}$ on day 1 to $10.33 \pm 0.38 \mathrm{gm} / \mathrm{dl}$ on day 30 .

In our study, there was a significant rapid increase in the serum ferritin level from $41.69 \pm 40.45 \mathrm{ng} / \mathrm{ml}$ on day 1 to $77.34 \pm 41.60 \mathrm{ng} / \mathrm{ml}$ on day 45 in IV iron group as compared to the oral iron group, from $22.20 \pm 8.82 \mathrm{ng} / \mathrm{ml}$ on day 1 to $31.72 \pm 9.72 \mathrm{ng} / \mathrm{ml}$ on day 45 (Table 2). These results are comparable to the study done by Bhandal and Russell ${ }^{14}$, as there was also a significant increase in the serum ferritin level in IV iron group from $13 \pm 3 \mathrm{ng} / \mathrm{ml}$ on day 1 to $42.2 \pm$ $7 \mathrm{ng} / \mathrm{ml}$ on day 40 as compared to the oral iron group, from $11 \pm 4 \mathrm{ng} / \mathrm{ml}$ on day 1 to $15 \pm 3 \mathrm{ng} / \mathrm{ml}$ on day 40 . In the study done by Kharde et $\mathrm{al}^{15}$, there was also a significant increase in the serum ferritin level in IV iron group from $11.47 \pm$ $1.655 \mathrm{ng} / \mathrm{ml}$ on day 1 to $53.47 \pm 5.011 \mathrm{ng} / \mathrm{ml}$ on day 40 as compared to the oral iron group, from $11.35 \pm 1.55 \mathrm{ng} / \mathrm{ml}$ on day 1 to $15.40 \pm 1.049 \mathrm{ng} / \mathrm{ml}$ on day 40 , that is also comparable to our study. In the study done by Pradhan et a ${ }^{16}$ also, there was a significant increase in the serum ferritin level in IV iron group from $11.920 \pm 0.936 \mathrm{ng} / \mathrm{ml}$ on day 1 to $53.885 \pm 5.111 \mathrm{ng} / \mathrm{ml}$ on day 45 as compared to the oral iron group, from $11.579 \pm 0.680 \mathrm{ng} / \mathrm{ml}$ on day 1 to $15.063 \pm$ $1.086 \mathrm{ng} / \mathrm{ml}$ on day 45 , that is also comparable to our study.

On the basis of currently available data, IV iron sucrose emerged out as a more convenient, safe and effective treatment option for women with postpartum iron deficiency anemia with advantages over oral iron, including a short treatment period, ensured compliance, no gastro-intestinal side effects and rapid replenishment of iron stores. It also reduces the need of blood transfusion in women with postpartum iron deficiency anemia as there are number of hazards of blood transfusion including transfusion of wrong blood, anaphylaxis and risk of transmission of infections, any of which would be devastating for the young mother.

\section{CONCLUSION}

Our study illustrate that intravenous iron sucrose administration increases the hemoglobin level more rapidly than oral intake of ferrous sulphate in women with iron deficiency anemia. It also replenishes iron stores more rapidly without any serious adverse effect than oral iron and it is safe and well tolerated. Administration of oral iron supplementations is not sufficiently enough in order to reverse anemia promptly, due to the limited absorption, the gastrointestinal symptoms and the poor compliance for long treatment of the patients. Thus, Intravenous iron sucrose is an effective, convenient, and safe route to cure postpartum anemia in comparison to oral iron supplementation.

\section{REFERENCES}

1. Cunningham FG, Leveno KJ, Bloom SL, Hauth JC, Gilstap LC, Wenstrom KD et al. Hematological Disorders. Cox SM, Werner CL, Hoffman BL, Cunningham FG eds. In : William's Obstetrics, $22^{\text {nd }}$ ed. New York, NY: McGraw Hill, 2005; pp 1144-5.

2. de Benoist D, McLean E, Egli I, Cogswell M. Worldwide prevalence of anaemia 1993-2005. WHO global database on anaemia. 2008.

3. World Health Organization. Maternal Health and safe motherhood programme \& WHO. Nutrition programme. The prevalence of anaemia in women : a 
tabulation of available information, $2^{\text {nd }}$ edi WHO. 1992. cited at https://apps.who.int/iris/handle/1665/58994

4. ACC/SCN (United Nations Administrative Committee on Coordination/Standing Committee on Nutrition). Fifth report on the world nutrition situation: Nutrition for improved development outcomes. Geneva, Switzerland, accscn@who.org, 2004.

5. Arias F. In : Practical guide to high risk pregnancy and delivery, $2^{\text {nd }}$ edition, p. 245 .

6. Dutta DC. Medical illness complicating pregnancy. In : Textbook of Obstetrics, $6^{\text {th }}$ edition. [Ed Konar H] The central Book Agency Pvt Ltd. Culcutta: 2004; p262-71.

7. Cunninghum FG, Lenevo KJ, Bloom SL, Hauth JC, Rouse DJ, Spong CY, Haematological disorder. Editor. In : Williams obstetrics, $23^{\text {rd }}$ edition. Philadelphia, McGraw Hill; 2010;1080.

8. Bhandal N, Russell R. intravenous versus oral iron therapy for postpartum anemia. BJOG 2006; 113(11):1248-52.

9. Kotto-Kome AC, Calhoun DA, Montenegro R, Sosa R, Maldonado L, Christensen MD. Effect of administering recombinant erythropoietin to women with postpartum anemia: a meta-analysis. J Perinatol 2004; 24:11-5.

10. Hypochromic anemias: Iron deficiency and Sideroblastic. In : DeGruchy's clinical hematology in clinical practice. Firkin F, Perington D, Rush B, Chesterman C. (eds). Blackwell Science Publication. Fifth edition. 1989. pp31-60.

11. Giannoulis C, Daniilidis A. Intravenous administration of iron sucrose for treating anemia in postpartum women. Hippokratia. 2009; 13(1):38-40.

12. Breymann $\mathrm{C}$. Treatment of iron deficiency anaemia in pregnancy and postpartum with special focus on intravenous iron sucrose complex. J Med Asso Thai. 2005; 88:S108-9.

13. Atkinson LA, Baxley EG. Postpartum fatigue. Am Fam Physician 1994; 50:113-8.

14. Policy on control of nutritional anemia. Ministry of health and Family Walfare, Government of India. Available from; http;/hetv.org/pdf/anaemiapolicy.pdf 1991.

15. Kharde PS, Bangal VB. dept. of obs. and gyne, rural medical college and pravara rural hospital and institute of medical sciences (Deemed University) Loni Ahmednagar, Maharashtra, India. IJBAR 2012; 03(04): 238-43.

16. Pradhan S, Patel O, Raju MD, Dash P. Study of oral versus intravenous iron therapy in postpartum anaemic women. J Evolution Med Dent Sci 2017; 6(54):4101-6. 